\title{
Analogue model of gravity driven deformation in the salt tectonics zone of northeastern Mexico
}

\section{Diego Gracia-Marroquín ${ }^{1}$, Mariano Cerca ${ }^{2, *}$, Dora Carreón-Freyre ${ }^{2}$, and Bernardino Barrientos-García ${ }^{3}$}

${ }^{1}$ Posgrado en Ciencias de la Tierra, Centro de Geociencias, Universidad Nacional Autónoma de México, Blvd. Juriquilla No. 3001, C.P. 76230, Juriquilla, Querétaro, Mexico.

${ }^{2}$ Laboratorio de Mecánica de Geosistemas, Centro de Geociencias, Universidad Nacional Autónoma de México,

Blvd. Juriquilla No. 3001, C.P. 76230, Juriquilla, Querétaro, Mexico.

${ }^{3}$ Centro de Investigaciones en Óptica A.C.,

Loma del Bosque No. 115, C.P. 37150, León, Guanajuato, Mexico.

*mcerca@geociencias.unam.mx

\begin{abstract}
In the deep seated gravity-driven deformation systems of the Gulf of Mexico contemporaneous extension and contraction of the overburden is favored by mechanical decoupling from the basement along thick salt sequences (up to $4 \mathrm{~km}$ ). The updip extension is located inland, on the continental shelf of northeast Mexico, and is characterized by extensional listric faults and roll-overs; the downdip shortening zone is located at the deep waters and is characterized by a fold and thrust belt detached above the salt layer. Two physical experiments are used to discuss some aspects of these gravity-driven systems. The experimental setup includes a motor-driven experimental table, an inclined brittle basement $\left(1^{\circ}\right)$, a silicone layer simulating the salt sequences, and sand layers simulating the pre-kinematic Jurassic-Cretaceous strata before Laramide shortening. Deformation resulted in further tilting of the basement $\left(3^{\circ}\right.$ to $\left.4^{\circ}\right)$. After the onset of deformation, thin sand layers were added at regular time intervals simulating the syntectonic sedimentation. The experiments reproduced the geometry of the deformation at the frontal ramp characterized by a seaward vergent thrust and its associated deformed region (the Perdido fold belt). The fold and thrust belt localization was favored by the change in basement inclination (a built-in slope change). Key elements interpreted in one available section of the area were reproduced in the model: a) the presence of an antithethic roll-over in the extensional zone and, b) the basinward vergence of folds and thrusts observed in the downdip shortening zone in the mexican Perdido fold belt.
\end{abstract}

Key words: gravity-driven deformation systems; Gulf of Mexico; Perdido fold belt; analogue modeling.

\section{RESUMEN}

En los sistemas de deformación asociada a procesos gravitacionales del Golfo de México, la extensión y el acortamiento contemporáneo de las secuencias de cobertura fueron provocados por el desacoplamiento mecánico entre la cobertura y el basamento a lo largo de secuencias salinas de gran espesor (hasta $4 \mathrm{~km}$ ). La extensión se localiza en la parte continental y en la plataforma del noreste de México, y se caracteriza por fallas lístricas extensionales y estratos de crecimiento con rotación sobre las fallas; la zona de acortamiento se encuentra en las aguas profundas y se caracteriza por un cinturón de pliegues y cabalgaduras despegado por encima de las capas de sal. En este trabajo se utilizan dos experimentos físicos para discutir aspectos selectos de estos sistemas. El arreglo experimental se construyó sobre una mesa automatizada e incluye un basamento quebradizo inclinado $\left(1^{\circ}\right)$, una capa de silicona que simula las secuencias de sal y capas de arena que simulan las secuencias precinemáticas del Jurásico-Cretácico, antes del acortamiento Laramide. Se llevó a cabo un acortamiento que resultó en una mayor inclinación del basamento $\left(3^{\circ} a 4^{\circ}\right)$. Durante y después de finalizar la etapa de acortamiento, se agregaron capas delgadas de arena a intervalos regulares de tiempo simulando la sedimentación sintectónica. Los experimentos reprodujeron la geometría de la deformación en la rampa frontal caracterizada por una cabalgadura con vergencia hacia el mar y su área deformada asociada (el cinturón plegado Perdido). La localización de la deformación en el cinturón de pliegues y cabalgaduras fue favorecida por el cambio en la inclinación del basamento. Dos elementos clave interpretados en una sección disponible del área de estudio fueron reproducidos en el modelo: a) la presencia de un roll-over antitético en la zona extensional y, b) la vergencia hacia la cuenca del cinturón de pliegues y la cabalgadura observados en la zona de acortamiento correspondiente a la zona mexicana del cinturón plegado Perdido.

Palabras clave: sistemas de deformación asociados a procesos gravitacionales; Golfo de México; cinturón plegado Perdido; modelado analógico.

\section{INTRODUCTION}

Gravity driven deformation systems occur all along the passive margin of the Gulf of Mexico, from the United States to Mexico. These systems are relatively well studied on the basis of seismic data

Gracia-Marroquín, D., Cerca, M., Carreón-Freyre, D., Barrientos-García, B., 2018, Analogue model of gravity driven deformation in the salt tectonics zone of northeastern Mexico: Revista Mexicana de Ciencias Geológicas, v. 35, núm. 3, p. 277-290. 
in the United States and are characterized by well-defined domains of linked updip extension and downdip contraction, caused by massive basinward salt flow, from Paleocene to Oligocene times (Trudgill et al., 1999; Peel et al., 1995; Salazar et al., 2013; Figure 1). Regionalscale profiles interpreted from seismic data allow to roughly image the intrinsic relationship between the two structural domains (Peel et al., 1995; Radovich et al., 2007; Rowan et al., 2004). The length scale involved in these gravitational systems is of more than $400 \mathrm{~km}$ from the updip extensional zone to the downdip shortening front. In the gravity driven systems of the Gulf of Mexico, a thick sedimentary overburden (on the order of 5 and up to $10 \mathrm{~km}$ ) moves above a layer of Jurassic salt interpreted to behave as a regional viscous detachment (Trudgill et al. 1999; Camerlo and Benson, 2006). Spreading is produced mainly by differential sedimentary loading of the prograding fluvial delta systems
(Rowan, 1995; Wu et al., 1990; Talbot, 1993; Diegel et al., 1995; Peel et al., 1995; Galloway et al., 2011), and deformation episodes in the extension-contraction systems coincide with episodes of lateral salt movement/expulsion (Vendeville, 2005; Brun and Fort, 2011). Massive displacements of salt seem to have occurred in response to sedimentary loading during the Cenozoic (Wu et al., 1990; Diegel et al., 1995; Peel et al., 1995; Galloway et al., 2011).

Just a few investigations have been published about the mexican salt tectonics (Macías, 2007; Le Roy and Rangin, 2008; Escalera-Alcocer, 2010) because of the legal rights restrictions of much of the seismicreflection and well data. In northeastern Mexico the extensional domain corresponds to the Burgos Basin, and the contractional domain located in deepwater at the mexican part of the Perdido fold and thrust belt (Pérez-Cruz, 1992; Ortiz-Ubilla and Tolson, 2004; Macías, 2007;

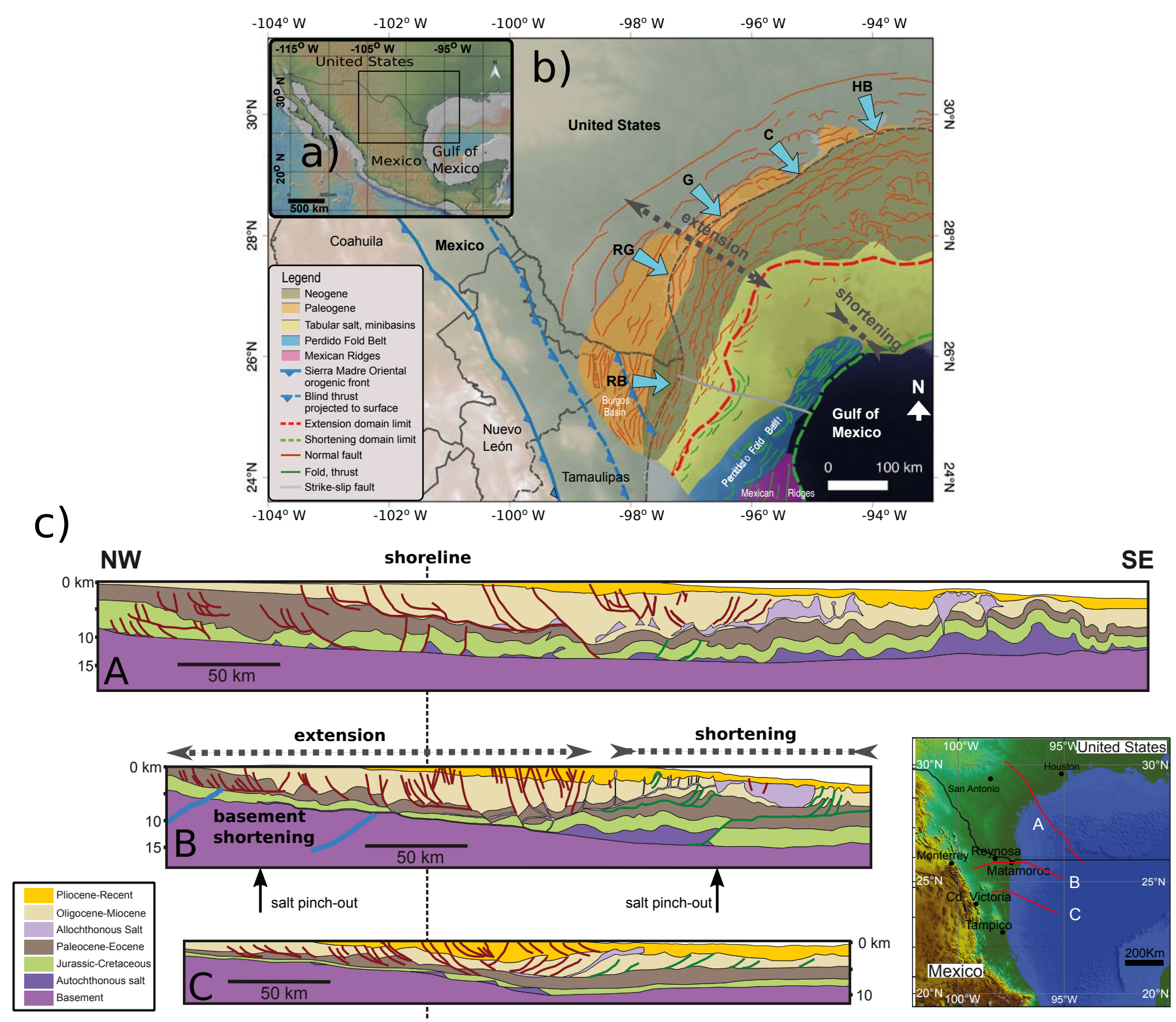

Figure 1. a) Location of the study area in the Gulf of Mexico; b) Sketch map showing the Laramide orogenic front (blue lines), the prograding fluvial-delta systems (blue arrows): Houston-Brazos (HB), Colorado (C), Guadalupe (G), Grande (RG) rivers and Río Bravo (RB) (after Diegel et al., 1995: Galloway et al., 2000; 2011; Rowan et al., 2004, Grando and McClay, 2004; English et al., 2003), and the structures in the mexican part of the salt tectonics provinces (SENER, SHCP, and CNH, 2015); c) Examples of geological sections interpreted by selected authors and their location within the salt tectonics province: A, Peel et al. (1995); B, EscaleraAlcocer (2010) and C, Macías, 2007. Section B was selected as the modeling target. The inset shows a map of the Gulf of Mexico illustrating the section locations. 
Escalera-Alcocer, 2010; Eguiluz de Antuñano, 2011). As in the United States counterpart, the system is deformed by differential loading; however, a closer inspection of some available seismic sections indicates that the extensional domain partially overlaps on the Laramide orogenic front in the western Burgos Basin limit in the Eocene (see map in Figure 1; Pérez-Cruz, 1992; Eguiluz de Antuñano, 2004; Ortiz-Ubilla and Tolson, 2004; Macías, 2007; Escalera-Alcocer, 2010). The presence of deep-seated blind thrusting affecting the pre-Jurassic basement interpreted in the seismic sections (Pérez-Cruz, 1992; Escalera-Alcocer, 2010), suggests that the Laramide shortening might have triggered gravity sliding by tilting to the east of the passive margin.

This paper discusses the architecture of gravitational systems of northeastern Mexico using two analogue models inspired by the available geological profiles and geological information of northeastern Mexico. We examine in particular the possible effects of the approaching of the Laramide orogenic front at the Paleocene on the structural style of the system.

\section{THE GRAVITY DRIVEN SYSTEMS OF NORTHEASTERN MEXICO}

We summarize some geometric aspects of the gravity driven systems of the Gulf of Mexico passive margin as described by several authors. During the opening of the Gulf of Mexico in the Middle Jurassic, the zone was flooded by the sea resulting in a widespread and massive (up to $4 \mathrm{~km}$ ) deposition of the Louann evaporites (Salvador, 1987). Salt was deposited in shallow basins during progressive extension and it is likely that deepening of the depocenters resulted in seaward salt flow and tendency to peneplanation of its top surface (Pindell and Kennan, 2007), prior to Cretaceous sedimentation. The continental margin and the salt were covered during the Late Jurassic and Cretaceous by carbonate sediments, and during the Cenozoic by basinward prograding sedimentary deltas. Complex deformation of the overburden and the expulsion of salt from a landward zone is thought to have begun during the Cenozoic as a response to sedimentary load (Wu et al., 1990; Diegel et al., 1995; Peel et al., 1995; Ge et al., 1997; Rowan et al., 2012). The structure of areas influenced by salt tectonics show important lateral variations because its original accumulation was controlled by the pre-existing rift topography (Salazar et al., 2013), and its later displacement is mainly a $3 \mathrm{D}$ process influenced by basementsalt-sedimentary overburden interaction (Rowan and Weimer, 1998). A section in northeastern Mexico interpreted by Escalera-Alcocer (2010) allows us to propose several key features that can be abstracted for the construction of the model based on the profile presented in Figure 1:

1. The seaward tilt of the pre-salt basement located below the extensional zone forms a ramp of $c a .3^{\circ}$ to $4^{\circ}$ in the area where salt was interpreted. The front of the fold-and-thrust belt of the Sierra Madre Oriental is located below the extension zone in the mexican profiles where folding and thrusting of the pre-Jurassic basement has been observed (Pérez-Cruz, 1992; Macías, 2007; Escalera-Alcocer, 2010; Figure 1). This deformation is probably related to the advance of the Laramide orogen front that arrived to the present-day position of the Sierra Madre Oriental front in the Paleocene (Pérez-Cruz, 1992; Eguiluz de Antuñano, 2011). Eastward tilting of the margin and subsidence was probably the main effect of the upward growth of the Laramide orogen in the area.

2. In the section presented by Escalera-Alcocer (2010) extension is located mainly in the continental zone, but normal faults are observed also in the continental platform. The structural style of the extensional domain is characterized by east-dipping, NW-SE oriented, listric faults, with extension migrating eastward through time (Pérez-
Cruz, 1992; Ortiz-Ubilla and Tolson, 2004; Macías, 2007; Morales, 2009). Two extensional detachment levels have been interpreted in the Burgos Basin. One located above the autochthonous Jurassic salt layer involving the Mesozoic sequence and another above Paleocene shale (Pérez-Cruz, 1992). The orientation of the extensional faults in the Burgos Basin coincides with the orientation of the orogenic front (Figure 1).

3. There is a large influx of Oligocene-Miocene sediment from the Río Bravo fluvial delta systems that coincides with the maximum deformation time for the Perdido fold-and-thrust belt (Galloway et al., 2011). The compilation of the regional stratigraphic columns (Figure 2) allow us to propose several sedimentary sets composing the syn-tectonic sequence: i) a Paleocene-Eocene sequence composed by limestone and shale at the Burgos Basin; ii) an Oligocene-Miocene sandstone layer recording the main deformation peak in the Perdido fold-and-thrust belt in the mexican part; ii) finally, a sequence of Pliocene-Recent sedimentary rocks.

4. Tilting might also have resulted in the generation of faultpropagation folds, suggested by the evidence found (SENER, SHCP, and $\mathrm{CNH}, 2015)$ in the mexican part of the Perdido fold-and-thrust belt.

\section{MODELING SET UP AND MATERIALS}

Since the beginning of the decade of 1990, two layer brittle-ductile analogue models have proven to be a proper technique to experimentally reproduce some mechanical conditions operating during salt tectonics processes (Vendeville and Cobbold, 1987; Cobbold and Szatmari, 1991; Vendeville and Jackson, 1992; Letouzey et al., 1995; Ge et al., 1997; Mauduit et al., 1997; Costa and Vendeville, 2002; Bonini, 2003; Fort et al., 2004; Vendeville, 2005; Brun and Fort, 2004, 2012; Baikpour et al., 2010; Wu et al., 2015). Analogue modeling provides an alternative to understand the processes involved in salt tectonics when the data available is scarce or of low quality, as is the case in northeastern Mexico. The basic setup, materials, and scaling conditions of our study were chosen according to mechanical models presented in the literature (Hubbert, 1937; Ramberg, 1981; Weijermars and Schmeling, 1986; Bonini, 2003). For experimental convenience, length ratio was fixed at $4 \times 10^{-6}(1 \mathrm{~cm}$ in the model represents approximately $2.5 \mathrm{~km}$ in nature $)$ and the experiments were carried out under normal gravity conditions. We carried out two experiments with tables 100 and $90 \mathrm{~cm}$ long, and 25 $\mathrm{cm}$ wide (Figure 3 ). The models were built on the experimental table located at the Laboratorio de Mecánica de Geosistemas (LAMG) of the Centro de Geociencias, Universidad Nacional Autónoma de México (UNAM) (Figure 3).

We have used two different granular materials to simulate brittle behavior: a) a dry and rounded, eolian, quartz sand (Ottawa sand) with bulk density of $\sim 1450 \mathrm{~kg} / \mathrm{m}^{3}$ for the sedimentary overburden and b) a denser quartz and corundum sand mixture of $1600 \mathrm{~kg} / \mathrm{m}^{3}$ for the brittle basement of the salt layer.

In nature, salt flows under relatively small shear stresses (Urai et al., 1986; Spiers et al., 1990; Weijermars et al., 1993; Hudec and Jackson, 2007 ) with a viscosity on the order of $10^{14}$ to $10^{19} \mathrm{~Pa} \cdot \mathrm{s}$ (Bonini, 2007). To reproduce the ductile creep of the salt layer we have used a silicone fluid similar to SGM36 (Weijermars and Schmelling, 1986) produced by GELEST with a density of $950 \mathrm{~kg} / \mathrm{m}^{3}$; thus, yielding a higher density contrast $(\sim 1.5)$ than the ratio sedimentary overburden/salt in the natural prototype ( 1.2). We have added an initial layer of silicone of around $1 \mathrm{~cm}$ thick, with a viscosity of $\eta=2.310^{4} \mathrm{~Pa} \cdot \mathrm{s}$ measured with a rotational viscometer; this material maintained the newtonian behavior when subjected to an engineering strain rate of $\sim 3.61 \times 10^{-6} \mathrm{~s}^{-1}$ at the 


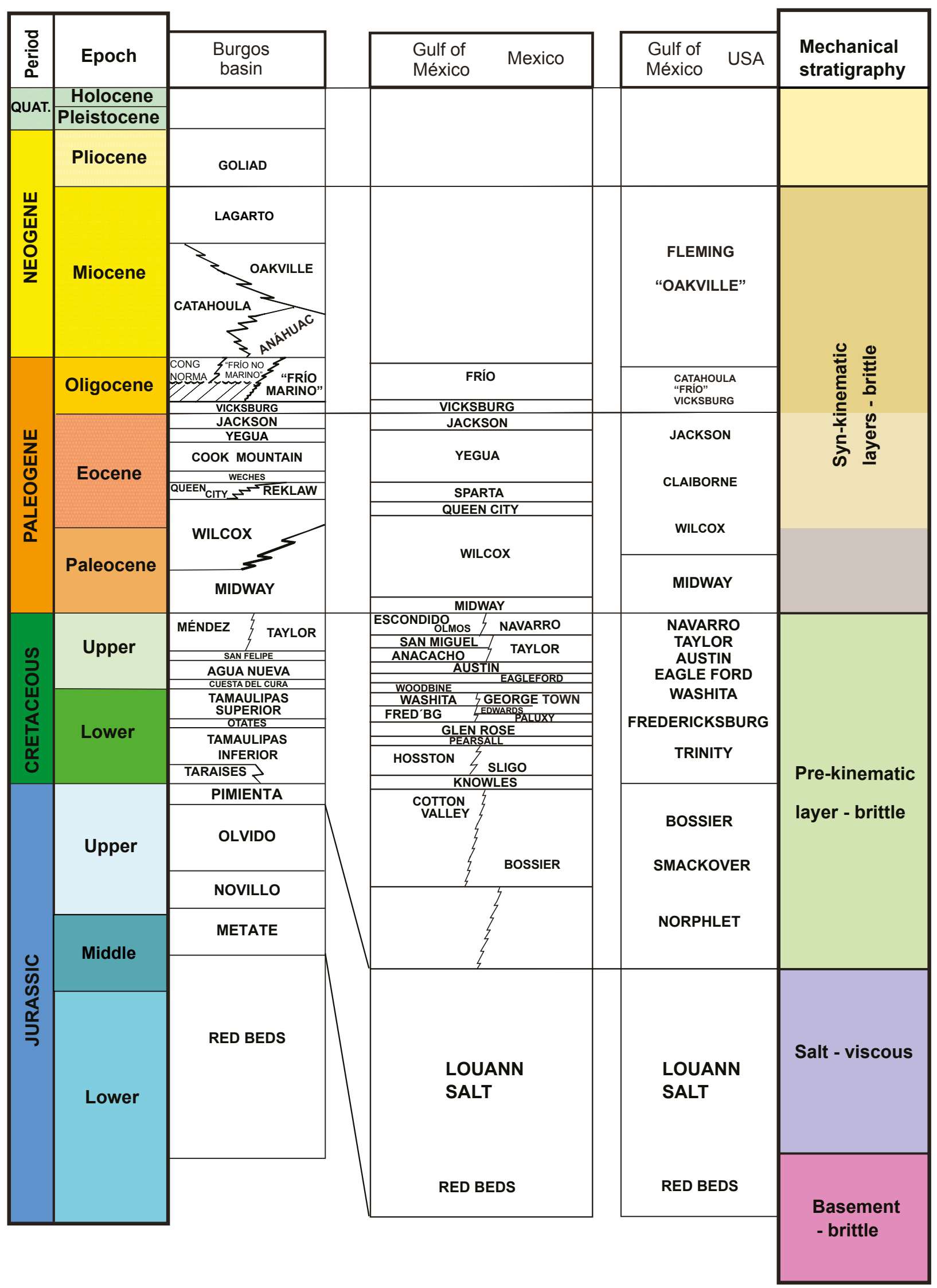

Figure 2. Composite stratigraphic columns in the Gulf of Mexico (compiled mainly after Galloway et al., 2000; Pérez-Cruz, 1992; Fiduk et al., 1999; Ortiz-Ubilla and Tolson, 2004; Eguiluz de Antuñano, 2011; SENER, SHCP, and CNH, 2015); and the mechanical stratigraphy used for the construction of the models. 
shortening phase. Engineering strain rate is calculated by dividing the velocity of the moving wall by the thickness of the viscous layer.

Previous experimental setups for salt tectonics in the Gulf of Mexico include the dominant spreading models (Ge et al., 1997; Rowan et al., 2012) or the dominant gliding setup (Fort et al., 2004; Brun and Fort, 2011; 2012). We have adopted the later model because of the geometrical characteristics of the natural prototype (Figure 4). In the presence of an inclined basement and salt layer (viscous) deformation, there is a combination of gliding and spreading as demonstrated by laboratory experiments (Brun and Merle, 1985). A discussion of the applicability for passive margins of these two models was presented by Brun and Fort $(2011 ; 2012)$ and Rowan et al. $(2012)$ which are beyond the scope of this paper.

The experimental procedures are described below:

a) We added a brittle basement layer on the table representing a heterogeneous pre-Jurassic basement. Half of the base layer, near to the moving wall, was constructed with a wedge geometry with basinward inclination, which had an angle of $\sim 1^{\circ}$ between upslope zone and downslope zone (Figure 3 ). This inclination increased to $3^{\circ}$ during
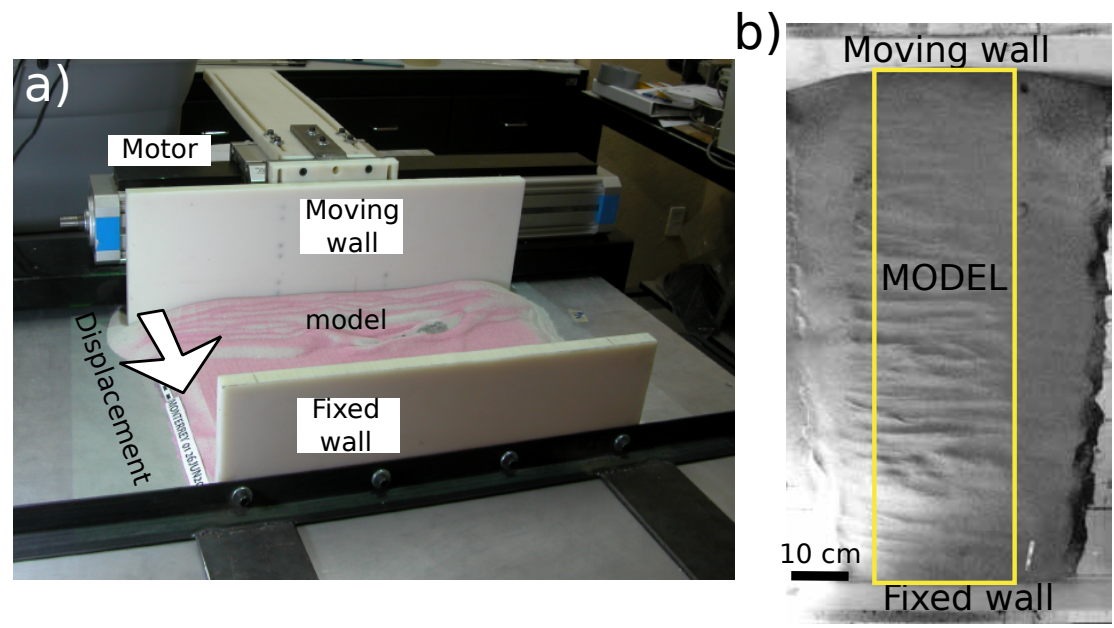

colored brittle dry quartz sand - synkinematic layer -sediments

$\square$ brittle dry quartz sand - prekinematic layer Jurassic-Cretaceous

$\square$ viscous silicone - Jurassic salt

$\square$ brittle dry corundum sand- pre-Jurassic basement

brittle glass microbeads

C) Initial conditions

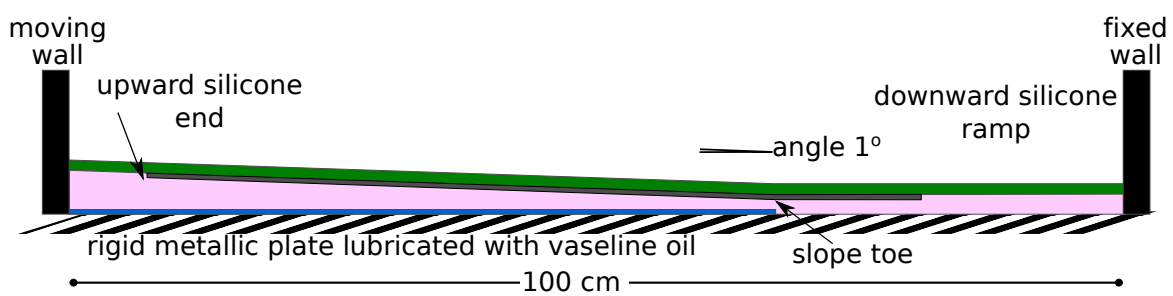

d) Model Shortening

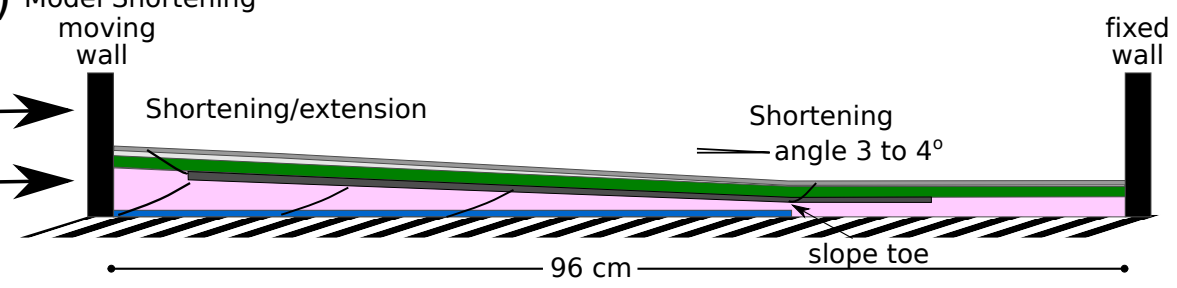

e) Sedimentary phase

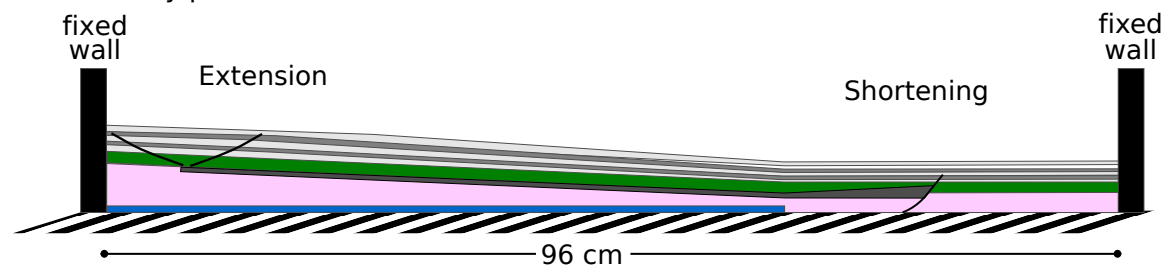

Figure 3. a) Experimental table used for the experiments, at the Laboratorio de Mecánica de Geosistemas, Universidad Nacional Autónoma de México; b) Plan view of a model. Sequential construction of the experimental setup; c) Initial conditions with constant thickness deposition of the pre-kinematic layer; d) Shortening phase and beginning of sedimentation (tilting of the basement), and e) Purely sedimentary phase. 
shortening. In order to more evenly distribute the slope of the basement during deformation, a $4 \mathrm{~mm}$-thin layer of compacted microbeads was added to the experimental table below the basinward slope zone.

b) For representing the Jurassic salt (Louann) we added a $1 \mathrm{~cm}$ thick layer of silicone putty covering partially the slope and the horizontal part of the basement. The updip termination near the extensional zone and the downdip ramp were located approximately at the position inferred in the geological section. The silicone layer is constrained by similar frictional boundary conditions on granular material at both, the upper and lower contacts.

c) The ductile layer was confined and overlain by a quartz sand layer of relatively constant thickness $(0.3 \mathrm{~cm})$ representing the JurassicCretaceous strata, a frictional carbonate rock sequence, that represents a nearly continuous thickness pre-kinematic layer. The model was contained laterally with sand to prevent silicone flow before the onset of the experiment and was left in this position for 24 hours to reach equilibrium.

d) Experiments were shortened approximately $4 \%$ in 3 hours by a mobile vertical wall moving at $1.3 \mathrm{~cm} \cdot \mathrm{h}^{-1}$. In the model, shortening simulates the Laramide Orogeny active during Paleocene-Eocene (Figure 3). During and after shortening sand was deposited on the model surface at regular time intervals to simulate syn-kynematic delta progradation (Figure 3). For clarity in visualization some layers of sand were differently colored. This sedimentation model is not intended to correspond in detail to the natural prototype but could be easily reproduced in a laboratory experiment.

During the experiment, top view images were recorded at regular time intervals. At the end of the experiment, models were saturated with water and cut into vertical sections to photograph the formed internal structures.

Before discussing results, it is important to mention the limitations of the models. The selection of the boundary conditions for these experiments was not a trivial and a simple idealized mechanical model cannot address all the variations and complexities encountered in natural salt tectonic systems. Isostatic compensation and thermal subsidence of the underlying lithosphere were not considered. Several authors have pointed out that when using low density silicone putties density scale is not properly considered (Vendeville, 2005; Brun and Fort, 2004; Allen and Beaumont, 2012). Allen and Beaumont (2012) have further pointed out that the buoyancy contrast can provoke some diapirs to appear in the model. However, the same authors also consider that the setup using SGM36 and sand is suitable for modeling salt tectonics in a submarine environment and that a pre-kinematic layer prevents formation of diapirs. Although these two conditions were assumed in the setup of our models, some diapirs formed at the boundaries of the ductile during the model deformation. Our experiments explore the possibility of margin tilting as a triggering mechanism for the onset of the gravity driven structurally linked systems. Other factors not considered that can have an effect in the deformation include: (a) the overall and lateral thickness variation of the salt layer that impacts the amount of resistance to shear, (b) thickness and strength of the overburden, (d) inclination of the subsalt basement, (e) lateral changes in lithofacies, (f) thermal subsidence of the basin, (g) lateral or radial flow of salt. The metallic base of the model was treated as a rigid and fixed substratum.

\section{EXPERIMENTAL RESULTS}

Two experiment runs showed similar results. In experiment 1 , the first observable structures in the overburden were folds in the slope zone. Folding progressed basinward beyond the slope toe but had not arrived to the silicone frontal ramp at the end of shortening phase. Folds formed contemporaneously in the down-dip zone. An interesting observation in both experiments is that folds were observed, first, on the surface in a position located above the slope toe and not at the frontal silicone ramp (Figure 5, see 960 minutes in the lower panel). Incipient thrusting and folding occurred also near to the moving wall. At the end of the shortening phase, the downslope shortening front was located between the slope change and the silicone ramp.

Early extension in the models was characterized by faults with surface traces oriented parallel to the moving wall. Normal faults on the surface appeared near the moving wall as an outer arc stretching in a buckling layer during bulk shortening. Some strike-slip faults formed in the central part of the model and acted as relays connecting the differential advance of folds. Extension related to the ductile displacement of silicone localized ahead of the shortening front at the end of this phase (Figure 5). In experiment 2, a larger amount of extension exposed the pre-kinematic layer. This was caused because the lower strain rate of the thicker silicone layer was slightly thicker in this experiment $(1.4 \mathrm{~cm})$. The extensional faults formed during the shortening phase, localized the deformation during the further evolution of the model.

After shortening, layers of colored, dry, quartz sand were added to the top of the model in order to simulate the Cenozoic sedimentary sequence. Sand layers were added at regular intervals (around 0.8 and $2.5 \mathrm{~mm} \cdot \mathrm{h}^{-1}$ for Experiments 1 and 2; respectively), taking care of leaving a greater thickness near the moving wall for suitably reproducing a deltaic sedimentation. The time span for the sedimentary phase was long ( 36 hours) and short (10 hours) for Experiments 1 and 2, respectively.

The first observable feature as the experiments continued in the sedimentary phase was folding grow-up at the down-dip zone, and development of the extensional zone parallel to the moving wall in the

\section{Setup of dominant gliding experiments for this work}

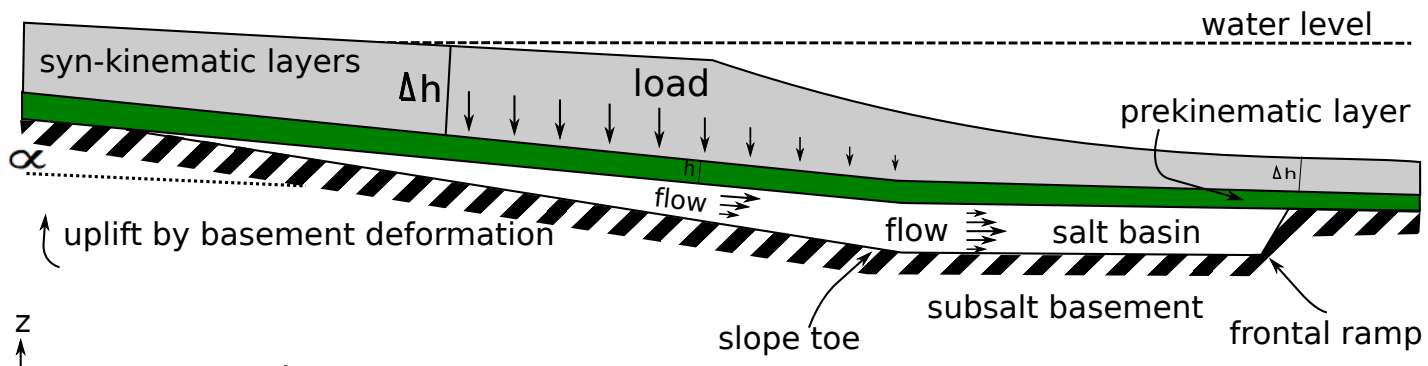

Figure 4. Cartoon showing the conceptual dominant gravity gliding setup used for the analogue models discussed in this paper. 

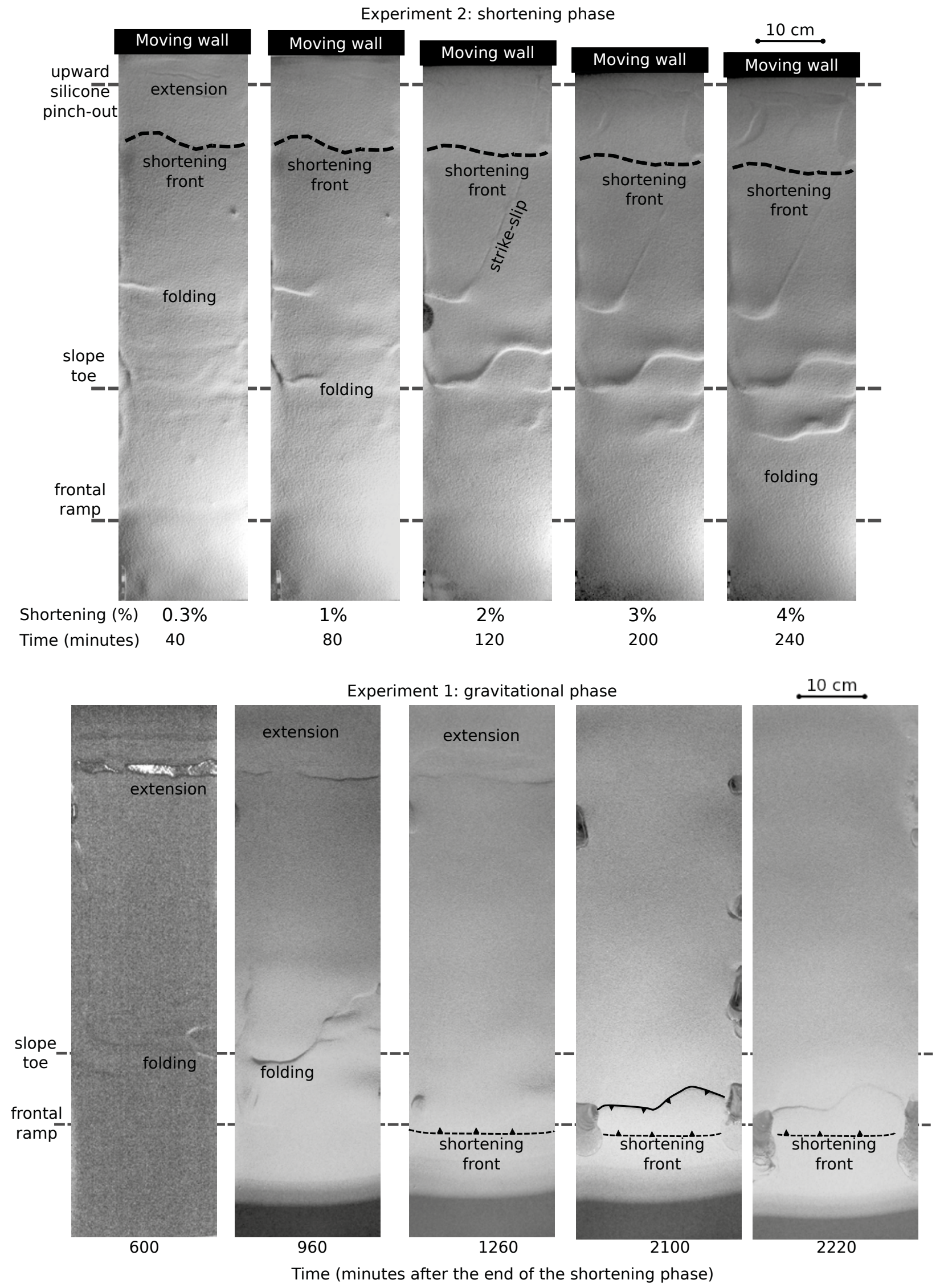

Figure 5. Sequence of plan view images of the experiments during the shortening (upper panel) and the sedimentary phase (lower panel). 
up-dip zone. With a relatively thin overburden (only the pre-kinematic layer and $4 \mathrm{~mm}$ of sedimentation; 600 and $960 \mathrm{~min}$ in Figure 5) extension $r$ exposed the silicone layer. In Experiment 1 shortening was observed at the frontal zone.

Folds grew in episodes alternating between underthrusting and accretion cycles. The interplay between sedimentary loading and silicone welding/expulsion inhibited propagation of some faults and favored the formation of new ones; therefore, several faults do not coincide spatially with those observed at the end of experiment. Whilst silicone thinned in the upward zone, deformation migrated basinward and some previously developed folds above the slope change were buried by the sediments. At the end of the experiment deformation was active near the front of the shortening zone $(2100$ and $2220 \mathrm{~min}$, Figure 5).

In Experiment 2 the forward migration of folding was observed from the slope toe to the frontal silicone ramp (Figure 5). Differences in fold displacement were accommodated by connecting strike-slip displacements. Extension at the updip zone also migrated slightly toward the basin. The migration of deformation was faster than in previous experiment. Normal faults continued to displace in the up-dip zone when more sedimentary loading was added. Experiments were stopped after the end of sedimentation when no further deformation was observed on the surface of the models.

Images of the Experiment 2 were processed for obtaining the surface topography during the evolution of the model using the optical technique described by Barrientos et al. (2008) that allowed a more detailed analysis of the model evolution. Figure 6 illustrates this quantitative evolution of the model surface; the images were generated by comparing the reference surface of the model (Figure 6a) with the corresponding deformed image using interferometric techniques (Figure $6 \mathrm{~b}$ to $6 \mathrm{j}$ ). The local height of the model modulates a projected illumination pattern in a point-by-point basis. The interpretation of the structures formed is drawn over the images. The digital elevation models highlight the progressive differential elevation between each photograph and the initial reference image. During the shortening phase (Figure $6 \mathrm{~b}$ and $6 \mathrm{c}$ ), the uplift propagated from the moving wall reaching a maximum of $1 \mathrm{~cm}$. Extensional faults were observed at the end of the shortening phase indicating a gravitational collapse enhanced by the silicone mobilization. Folds formed at the slope zone and propagated beyond the slope toe at the end of the shortening phase. Differential slip of the overburden is indicated by the location of folds and the strike-slip faults linking fold hinges (Figure 6c). During the sedimentary phase (Figure 6e to 6j) both, the extensional and shortening zones, migrated basinward. The image sequence of the sedimentary phase also illustrates how structures trap the prograding sediments in local depocenters (Figure 6e). Shortening reaches the silicone ramp at the late experimental times (Figure 6j).

In order to facilitate description of the sections, the updip zone is near to the moving wall at the west, and the distal downdip zone is located at the east. The structures formed in the models are similar to those commonly found in natural gravity driven deformation systems. The overall effect of shortening was the basinward tilting of the basement below the silicone layer reaching $3^{\circ}$, and even, $4^{\circ}$ was achieved locally at the zone near to the moving wall. The cross sections show well defined zones of extension and shortening in the overburden, as well as basement tilting (Figure 7).

The Figure 7 show section examples illustrating variations in the resulting deformation style. Uplift of the brittle subsalt basement by thrusting and folding associated with the shortening phase is observed in the western part of the model, forming an inclined plane of $3^{\circ}$ towards the basin. A thrust upper tip formed just at the upward border of the silicone coinciding with the localization of an extensional fault.
In the two experiments, the extensional zone is characterized by the formation of an antithethic roll-over that began to form at the end of the shortening phase. In Experiment 1 the early activity of conjugate normal faults and silicone depletion results in the formation of a turtleback structure, a common structure formed in thin-skinned deformation. The turtle back anticline is bounded by antithetic and synthetic rollovers developed diachronously during extension and sedimentation. The silicone formed two rollers below the faults and was extracted from below the turtle-back anticline welding the overburden and the basement. The Laramide thrusts are located in the natural prototype below the zone of salt expulsion where the sedimentary overburden is characterized by extensional deformation. This feature might suggest that the overburden glided over the salt whilst the basement was uplifting and the salt mechanically decoupled the system.

The extension zone in Experiment 2 is marked by the development of the antithethic roll-over (Figure 7). A basinward migration of the extensional zone was observed in one of the cross sections. In both experiments the silicone allowed an extreme form of thin-skin extension known as raft tectonics (Duval et al., 1992; Jackson and Talbot, 1991; Gemmer et al., 2004; Brun and Fort, 2011) in which horizontal displacements dominate. The translation zone experienced less deformation and only incipient folding was observed. At the slope zone, the silicone was locally expelled from the translation zone forming welds. Thickening of the silicone layer was observed both, laterally and down-dip.

The shortening zone is characterized by a fold and thrust belt detached above the silicone layer but the style varied between the two experiments. In Experiment 1 (Figure 7a), a roof duplex formed between two opposite vergence thrusts and the roof is forming a weld. In Experiment 2 (Figure 7b), it was observed the formation of detachment folds with opposite vergence delimited by thrusts. The silicone thickened at the central part of the shortening area generating subsidence at the adjacent zones. Sediments filled this space. A prograding frontal monocline and a thrust form a composite roof duplex. Also, we observe a pinched-out synclinal in the zone of strong shortening. The structure developed to a growth syncline in the sedimentary phase layers. By contrast, in the Experiment 2 (Figure 7c), the contraction style is characterized by basinward vergent imbricate thrusting.

Overall, the model results show well defined and localized zones of extension, translation, and shortening in a structurally linked system. It is important to note that the extensional faults of the model are limited to a narrow zone, whereas the geological sections show a more complex extensional zone that migrated seaward through time. This discrepancy may indicate that our model oversimplifies the salt system. A scenario where these processes would be associated with other factors causing the instability of the system, such as thermal loading caused by extension (Rangin et al., 2008), lateral or radial spreading of salt, and other tectonic displacements, as well as the presence of a continental shelf may generate a pattern of extension resembling more closely the observed extensional pattern in the geological sections.

\section{DISCUSSION}

The timing of salt mobilization in the Gulf of Mexico coincides with periods of vigorous regional sedimentation. During the Eocene and up to early Oligocene times, the fluvial delta systems were active (Galloway et al., 2011) and salt was continuously mobilized seaward. In Oligocene-Miocene times the main peak of deformation in the Perdido fold-and-thrust belt (Camerlo and Benson, 2006) coincides with the peak of sedimentary load provided by the Houston-Brazos 


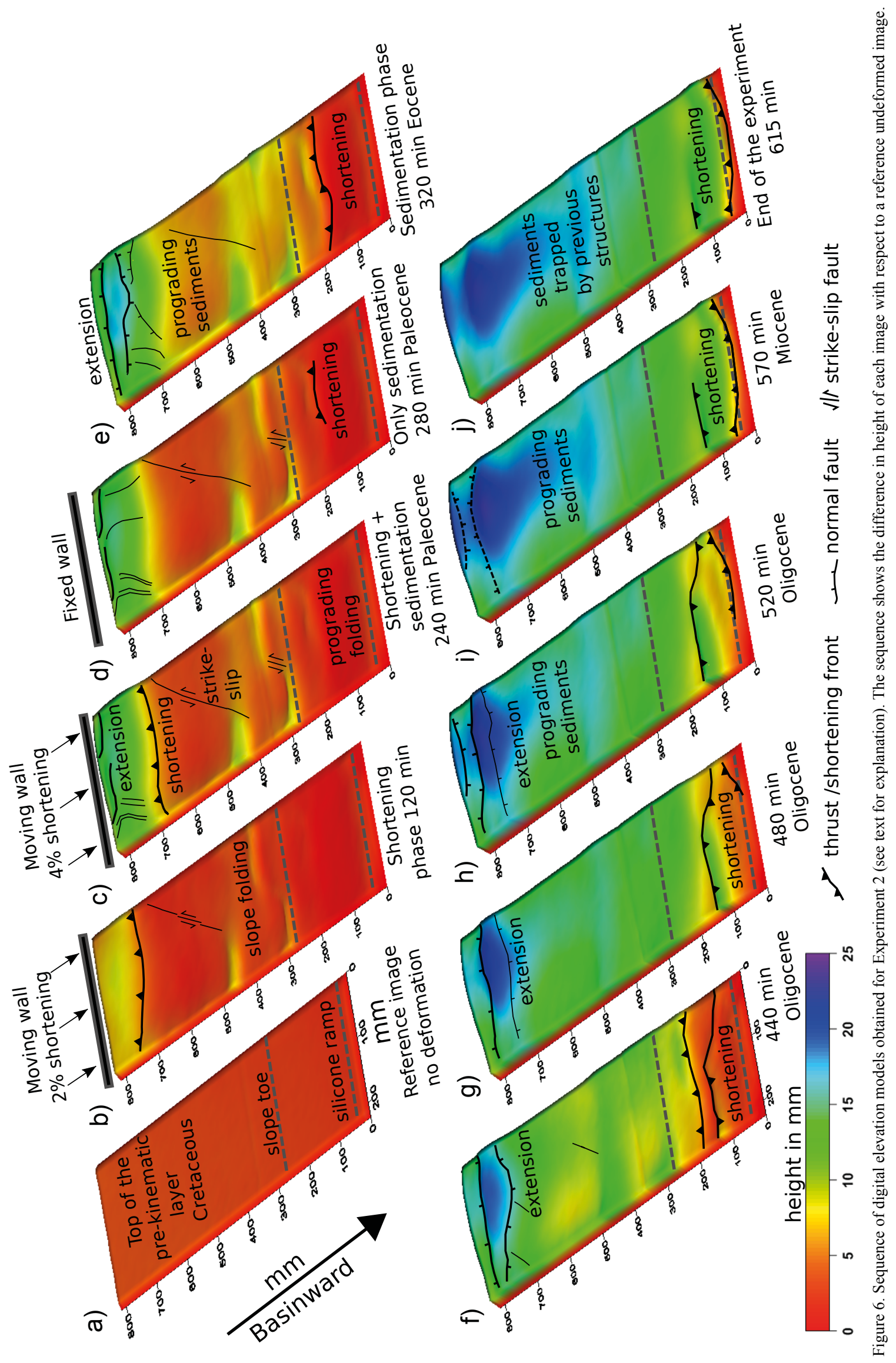



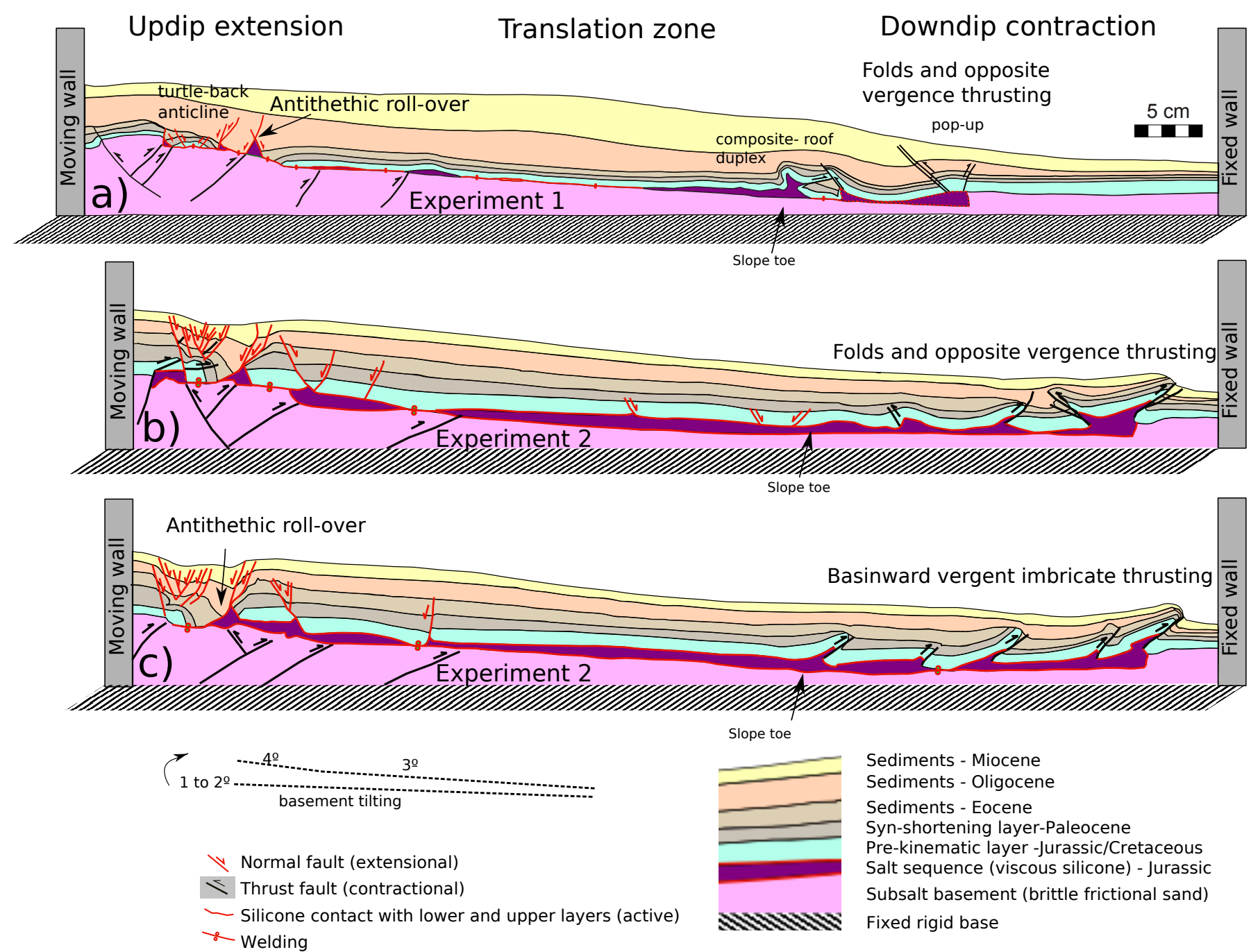

Figure 7. Three representative sections of experiments (a - Experiment 1; b and c - Experiment 2). Differences in the contractional style suggest that deformation in these systems is highly heterogeneous in 3D. Note the formation of folds in the zone of the slope toe. The updip extensional zone is characterized by the presence of an antithethic roll-over affecting the pre-kinematics layer.

and Grande-Bravo delta systems (Figure 1). Regional gravitational motions along the Gulf of Mexico coast occurred at this time caused mainly by the sedimentary loading (Wu et al., 1990; Diegel et al., 1995; Peel et al., 1995; Ge et al., 1997; Rowan et al., 2012). In this hypothesis, deformation of the system occurs dominantly by gravitational spreading (Rowan et al., 2012).

The model results presented explore the influence of the Laramide shortening advance on the gravity-driven salt system, and particularly on the diversity of extensional and shortening structures. The Laramide orogeny was a regional event of east directed shortening deformation which affected northeastern Mexico during Late Cretaceous-middle Eocene time span (80 to $35 \mathrm{Ma}$; Ye, 1997; Eguiluz de Antuñano et al., 2000; 2004; Chávez Cabello et al., 2011). In the southernmost part of the saline domain, the structural linked systems are closer to the Laramide orogenic that reached the Burgos Basin area (Pérez-Cruz, 1992; Eguiluz de Antuñano, 2004; 2009; Chávez Cabello et al., 2011). The recognition of basement shortening and its relevance to deformation in the Burgos Basin is not a new idea and was already pointed out previously by Pérez-Cruz (1992). Two major erosional unconformities in the Burgos Basin at 48.5 and 39.5 Ma have been linked to orogenic deformation pulses (Eguiluz de Antuñano, 2011). Furthermore, the profile interpreted and reported by Escalera-Alcocer (2010) shows eastward vergent blind thrusting, affecting the pre-Jurassic basement and the Cretaceous sequence in the Burgos Basin just below the assumed zone of original salt deposition.

The idea of local gravity gliding as a result of mountain building during the Laramide Orogeny in northeastern Mexico was also proposed by Trudgill et al. (1999). These authors did not rule out the idea of full gliding but favored the classical model of gravitational spreading. In the US, the resulting extensional pattern from spreading defines a radial set of distributed extensional fault zones with motion converging to the ultradeep waters and delimited by lateral transfer faults (Figure 1; Cobbold and Szatmari, 1991; Diegel et al., 1995; Brun and Fort, 2012). When approaching southward to the Río Bravo the extensional fault pattern is disrupted abruptly and the traces tend to align with the Laramide shortening front and concentrate in a narrower band of deformation. This abrupt change in the structural pattern has been interpreted as produced by a fault zone inherited from the Jurassic opening of the Gulf and reactivated at the late Laramide deformation in the Eocene (Flotté et al., 2008). Deep-seated basement 
a)

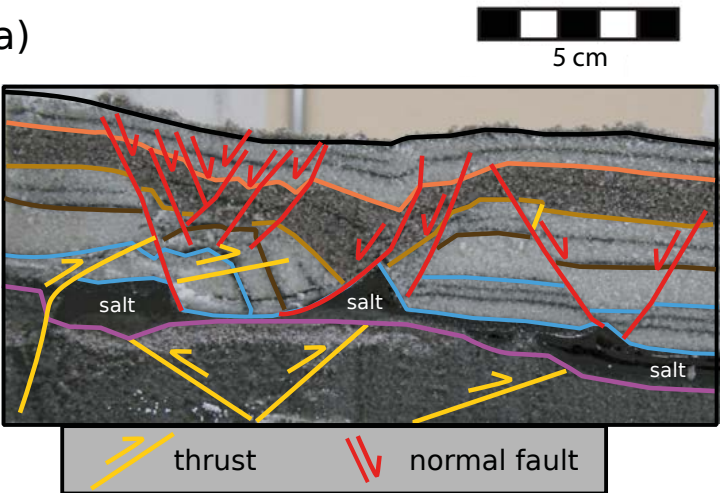

c)

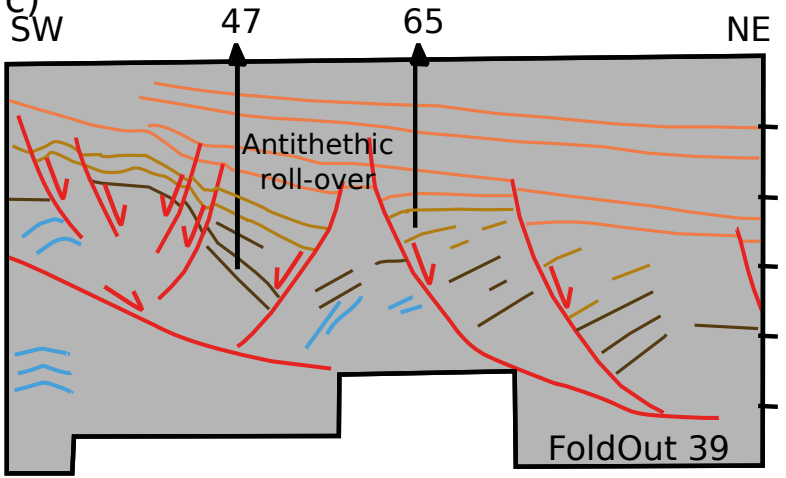

b)

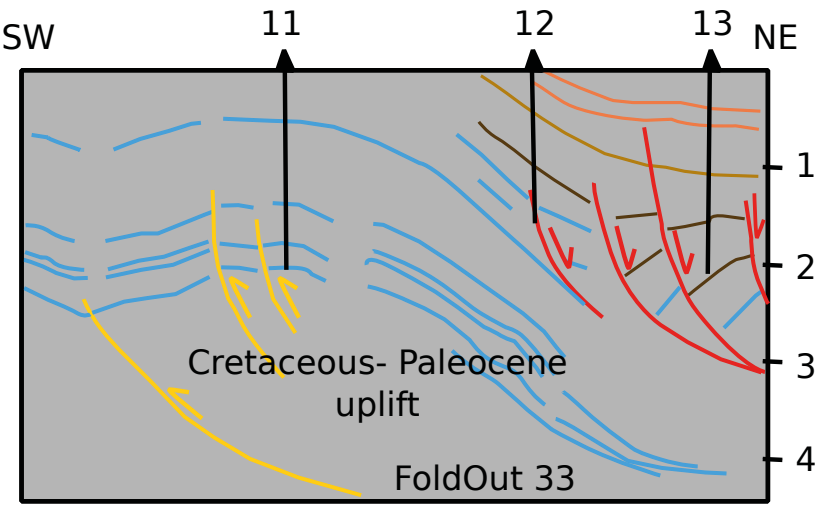

d)
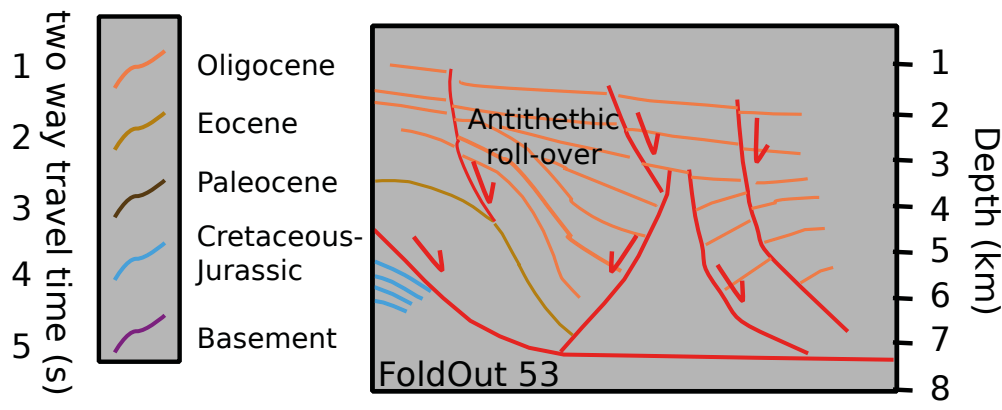

Figure 8. a) Closeup of the model results in the extensional zone showing the formation of an antithethic rollover controlled by gliding of the prekinematic layer; in the model, the location of the roll-over was controlled by the basement uplift. b) Line drawing of a time profile in the Burgos Basin showing the relations observed between orogenic uplift and extension. c), d) Line drawings of seismic profiles in the Burgos Basin essentially parallel to the salt tectonic systems showing the presence of an antithethic roll-over parallel to the buried orogenic front. b), c), and d) are redrawn images from the work of Pérez-Cruz (1992, foldouts 35, 39, and 53), not set to a rigorous scaling and vertical exaggeration; numbers refer to the exploratory wells used by the author to constrain the chronostratigraphy of the seismic sections.

fault displacements might also have enhanced gravity deformation on the margin south of the study area in the Mexican Ridges in Miocene times (Le Roy et al., 2008).

The evidences discussed before suggest that shortening played a role in the large scale subsidence and margins tilting leading to the formation of the linked structural systems. The model reproduces the deformation of the basement and tilting as a byproduct of thrusting. We also have reproduced the sedimentary loading that was active from Eocene to Miocene times. We propose that the onset of the gravitational deformation was synchronous with Laramide orogeny and that salt began to flow with a change in the margin angle (from $1^{\circ}$ to $3^{\circ}$ ). Our model results do not demonstrate directly that tilting occurred, however they show that this is an additional mechanism that needs to be considered for studying deformation in these gravitational systems in the mexican part of the Gulf of Mexico.

Figure 8 shows a comparison between our model results in the extensional zone and examples of the relations among the uplift and extension in the Burgos Basin (Pérez-Cruz, 1992). Major erosion episodes in the Burgos Basin are also coincident with the migration events of the Laramide uplift that, on the other hand, might have been active in the zone until deposition of the Yegua Formation (around 35 Ma) according to Eguiluz de Antuñano (2009; 2011).

The model cross sections show well defined and localized zones of extension, translation, and shortening. Our models are idealized representation of nature and were focused on shortening as triggering mechanism of salt mobility, comparison with real sections that include other processes such as diapirism and allochtonous salt would overuse the obtained data. Thus, the mexican area of the Gulf of Mexico still remains as a poorly understood issue. Nevertheless, based on the available seismic profiles, geological information, and integration of the analogue model results, we interpret some of the structures observed in the model and their corresponding nature counterpart.

The models results showed that an antithethic roll-over was formed in the highly extended zone (Brun and Mauduit, 2009) where the silicone was mobilized. This structure has been observed in a United States seismic section (Peel et al., 1995) involving a complete sequence from the Jurassic to the Paleocene, and in the platform zone of the Burgos Basin in Mexico (Pérez-Cruz, 1992).

Shortening in the models propagated basinward until reaching the frontal salt ramp. It was observed that the slope toe has an important influence in localizing the formation of the first buckle folds and anticlines. Shortening in the experiments reproduced the geometry of the deformation at the frontal ramp, characterized by a seaward vergent thrust and its associated fold belt (Figure 9). Differences in the shortening style, as well as the zones of salt accumulation, reproduced in the model are also observed in the seismic profiles. The fold belt behind the frontal ramp is characterized by growth syncline and pinched-out synclines. The formation of growth synclines in the model was related to development of a pop up structure in the domain of strong shortening. Shortening in the Escalera-Alcocer (2010) profile and in our model results are more intense than those reported in the corresponding area in the northern Gulf of Mexico. 
a)

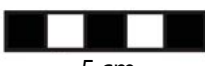

$5 \mathrm{~cm}$

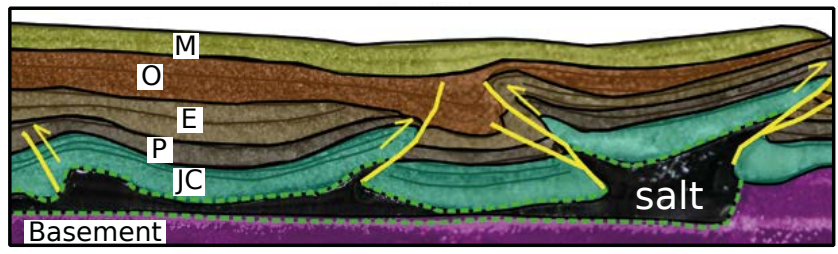

c)

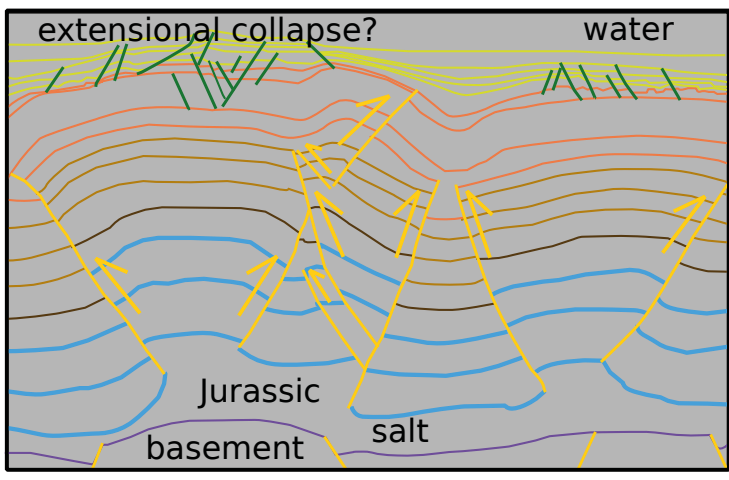

b)

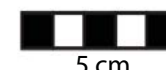

$5 \mathrm{~cm}$

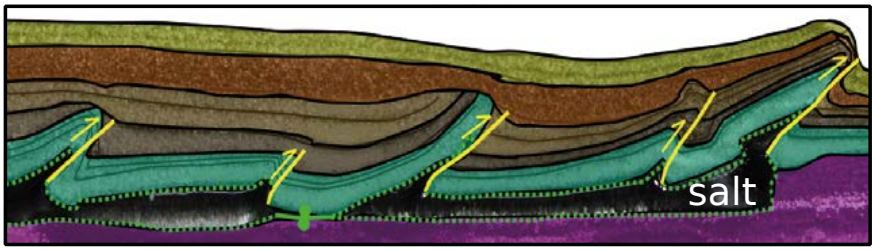

d)

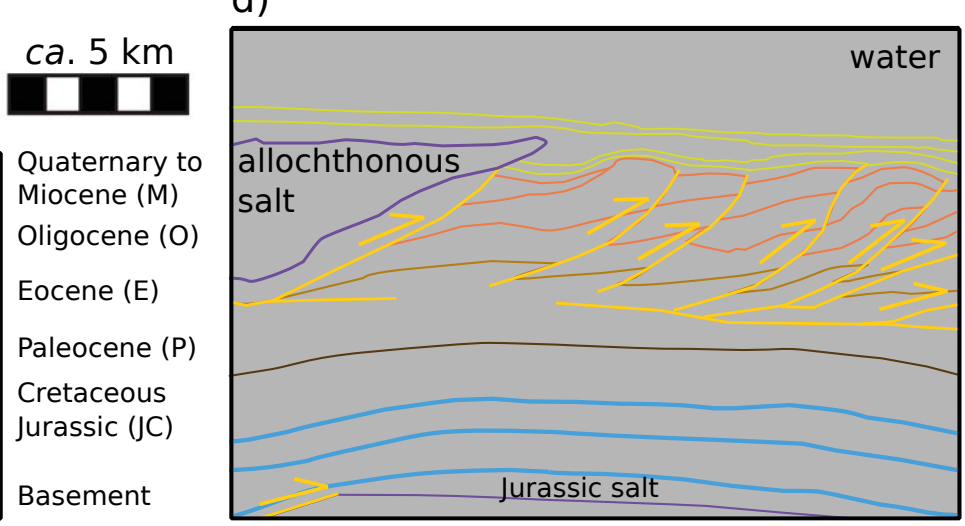

Figure 9. Closeup of the model results illustrating two shortening styles observed in the downdip contraction zone: a) Opposite vergent folds bounded by thrusting, and b) Basinward vergent imbricated thrusting. c), d) Line drawings redrawn from SENER, SHCP, and CNH (2015) showing the shortening styles observed in different zones of the mexican Perdido Fold and Thrust Belt.

\section{CONCLUSIONS}

The correlation between physical experiment and the gravity driven systems in northeastern Mexico underline the influence of tilting of the passive margin during Laramide Orogeny for triggering gliding deformation. The results suggest that basement tilting can have induced the mobilization of the salt layer. This does not rule out that differential loading deformation continued during the subsequent sedimentary deposition of deltas. In northeastern Mexico the gravity sliding process was enhanced because the salt was located near the orogenic front. The experiment reproduces the zones of extension, translation, and shortening observed in a gravity driven system in nature. In particular, shortening characteristics of the Perdido fold-and-thrust belt.

In the presence of a tilted basement, the detachment folds are delimited by opposite vergent thrust or developed a basinward vergence and imbrication. Differential sedimentary loading controlled the formation and evolution of the salt tectonics structure after the initial tilting of the subsalt basement. Since our experiments are simplified, further mechanical and dynamical complexities should be tested to verify those findings. The model results do not explain all the structural diversity observed in the sections that can be caused by factors not considered in the mechanical model such as a complex thermal evolution, lithofacies changes, among others.

\section{ACKNOWLEDGEMENTS}

This investigation was partially funded by project PAPIITIN115214 to Mariano Cerca. Diego Gracia-Marroquín also acknowledges CONACyT for providing an M.Sc. scholarship. We acknowledge Ricardo Carrizosa and Rodrigo Portillo for their help in the preparation of the analogue materials used for the experiments. Carlos Mares kindly helped with the analysis of the deformation in the models.

\section{REFERENCES}

Allen, J., Beaumont, C., 2012, Impact of inconsistent density scaling on physical analogue models of continental margin scale salt tectonics: Journal of Geophysical Research, 117, B08103. doi:10.1029/2012JB009227.

Baikpour, S., Zulauf, G., Sebti, A., Kheirolah, H., Dieti, C., 2010, Analogue and geophysical modelling of the Garmsar Salt Nappe, Iran: constraints on the evolution of the Alborz Mountains: Geophysical Journal International, 182(2), 599-612, DOI: 10.1111/j.1365-246X.2010.04656.8.

Barrientos, B., Cerca, M., García-Márquez, J., Hernández-Bernal, C., 2008, Three-dimensional displacement fields measured in a deforming granularmedia surface by combined fringe projection and speckle photography: Journal of Optics, 10(10), 104027, 10 pp.

Bonini, M., 2003, Detachment folding, fold amplification, and diapirism in thrust wedge experiments: Tectonics, 22(6), 1065-1076, DOI: $0.1029 / 2004 J B 003552$.

Bonini, M., 2007, Deformation patterns and structural vergence in brittle-ductile thrust wedges: An additional analogue modelling perspective: Journal of Structural Geology, 29, 141-158.

Brun, J.-P., Fort, X., 2004, Compressional salt tectonics (Angolan margin): Tectonophysics, 382(3-4), 129-150, DOI: 10.1016/j.tecto.2003.11.014.

Brun, J.-P., Fort, X., 2011, Salt tectonics at passive margins: Geology versus models: Marine and Petroleum Geology, 28(6), 1123-1145, DOI: 0.1016/j. marpetgeo.2011.03.004

Brun, J.-P., Fort, X., 2012, Salt tectonics at passive margins: Geology versus models - Reply: Marine and Petroleum Geology, 37(1), 195-208.

Brun, J.-P., Mauduit, T.P.O., 2008, Rollovers in salt tectonics: the inadequacy of the listric fault model: Tectonophysics, 457, 1-11.

Brun, J.-P., Mauduit, T.P.O., 2009, Salt rollers: Structure and kinematics from analogue modelling: Marine and Petroleum Geology, 26(2), 249-258, DOI: 10.1016/j.marpetgeo.2008.02.002.

Brun J-P., Merle O., 1985, Strain patterns in models of spreading-gliding nappes: Tectonics, 4(7), 705-719.

Camerlo, R.H., Benson, E.F., 2006, Geometric and seismic interpretation of the Perdido fold belt: Northwestern deep-water Gulf of Mexico: American Association of Petroleum Geologists Bulletin, 90, 363-386. 
Cobbold, P.R., Szatmari, P., 1991, Radial gravitational gliding on passive margins: Tectonophysics, 188, 249-289.

Costa, E., Vendeville, B.C., 2002, Experimental insights on the geometry and kinematics of fold-and-thrust belts above weak, viscous evaporitic decollement: Journal of Structural Geology, 24(11), 1729-1739, DOI: 10.1016/S0191-8141(01)00169-9.

Chávez-Cabello, G., Torres-Ramos, J.A., Porras-Vázquez, N.D., Cossío-Torres, T., Aranda-Gómez, J.J., 2011, Evolución estructural del frente tectónico de la Sierra Madre Oriental en el Cañón Santa Rosa, Linares, Nuevo León: Boletín de la Sociedad Geológica Mexicana, 63(2), 253-270.

Diegel, F.A., Karlo, J.F., Schuster, D.C., Shoup, R.C., Tauvers, P.R., 1995, Cenozoic Structural Evolution and Tectono-Stratigraphic Framework of the Northern Gulf Coast Continental Margin, in Jackson, M.P.A., Roberts D.G., Snelson, S. (eds.), Salt tectonics: a global perspective: American Association of Petroleum Geologists Memoir, 65, 109-151.

Duval, B., Cramez, C., Jackson, M.P.A., 1992, Raft tectonics in the Kwanza Basin, Angola: Marine and Petroleum Geology, 9, 389-404.

Eguiluz de Antuñano, S., Aranda-García, M., Marret, R., 2000, Tectónica de la Sierra Madre Oriental, México: Boletín de la Sociedad Geológica Mexicana, 53, 1-26.

Eguiluz de Antuñano, S., 2004, Tectónica Laramide en la Cuenca de Burgos, Mexico, Reunión Anual de la Unión Geofísica Mexicana 2004, <http:// www.ugm.org.mx/publicaciones/geos/pdf/geos04-2/sesiones_especiales/ SE04.pdf $>$, consulted: february 12, 2015.

Eguiluz de Antunano, S., 2009, The Yegua Formation: Gas Play in the Burgos Basin, Mexico, in Bartolini C., Roman Ramos, J.R. (eds.), Petroleum systems in the southern Gulf of Mexico: American Association of Petroleum Geologists Memoir, 90, 49-77, DOI:10.1306/13191077M902621.

Eguiluz de Antuñano, S., 2011, Sinopsis geológica de la Cuenca de Burgos, noreste de México: producción y recursos petroleros: Boletín de la Sociedad Geológica Mexicana, 63(2), 323-332.

English, J.M., Johnston, S.T., Wang, K., 2003, Thermal modelling of the Laramide orogeny: testing the flat-slab subduction hypothesis: Earth and Planetary Science Letters, 214, 619-632.

Escalera-Alcocer, J.A., 2010, Estrategia, logros y desafíos de la exploración petrolera en México, Trabajo de Ingreso a la Academia de Ingeniería, Especialidad Ingeniería Geológica, 67 Pp. <http://www.ai.org.mx/ai/ archivos/ingresos/escalera/Estrategia\%20logros\%20y\%20desafios $\% 20$ de\%20la\%20exploracion\%20petrolera\%20en\%20Mexico.pdf $>$, consulted sept. 11, 2015.

Fiduk, J.C., Weimer, P., Trudgill, B.D., Rowan, M.G., Gale, P.E., Korn, B.E., Phair, R.L., Roberts, G.R., Gafford, W.T., Lowe, R.S., Queffelec, T.A., 1999, The Perdido fold belt, northwestern deep Gulf of Mexico: Part 2. Seismic stratigraphy and petroleum systems: American Association of Petroleum Geologists Bulletin, 83, 578-612.

Flotté, N., Martínez, J., Rangin, C., Husson, L., Tardy, M., Le Pichon, X., 2008, The Río Bravo fault, a major late Eocene-Oligocene left-lateral shear zone: Bulletin de la Societé Géologique de France, 179(2), 147-160.

Fort, X., Brun, J.-P., Chauvel, F., 2004, Salt tectonics on the Angolan margin, synsedimentary deformation processes: Bulletin of the American Association of Petroleum Geologists, 88, 1523-1544.

Galloway, W.E., Ganey-Curry, P.E., Li, X., Buffler, R.T., 2000, Cenozoic depositional history of the Gulf of Mexico basin: American Association of Petroleum Geologists Bulletin, 84(11), 1743-1774.

Galloway, W.E., Whiteaker T. L., Ganey-Curry, P., 2011, History of Cenozoic North American drainage basin evolution, sediment yield, and accumulation in the Gulf of Mexico basin: Geosphere, 7(4), 938-973, DOI:10.1130/GES00647.

Ge, H., Jackson, M.P.A., Vendeville, B.C., 1997, Kinematics and dynamics of salt tectonics driven by progradation: American Association of Petroleum Geologists Bulletin, 81, 398-423.

Gemmer, L., Ings, S.J., Medvedev, S., Beaumont, C., 2004, Salt tectonics driven by differential sediment loading: Stability analysis and finite element experiments: Basin Research, 16, 199-219.

Grando, G., McClay, K., 2004, Structural evolution of the Frampton growth fold system, Atwater Valley-southern Green Canyon area, deep water Gulf of Mexico: Marine and Petroleum Geology, 21(7), 889-910.

Hubbert, M.K., 1937, Theory of scale models as applied to the study of geologic structures: Bulletin of the Geological Society of America, 48, 1459-1520.
Hudec, M.R., Jackson, M.P.A., 2007, Terra infirma: Understanding salt tectonics: Earth-Science Reviews, 82, 1-28.

Jackson, M.P.A., Talbot, C.J., 1991, A glossary of salt tectonics: University of Texas at Austin, Bureau of Economic Geology, Geologic Circular 91-4, $44 \mathrm{pp}$.

Le Roy, C., Rangin, C., 2008, Cenozoic crustal deformation of the offshore Burgos basin region (NE Gulf of Mexico). A new interpretation of deep penetration multichannel seismic reflection lines: Bulletin de la Societé Géologique de France, 179(2), 161-174.

Letouzey, J., Colletta, B., Vially, R., Chermette, J.C., 1995, Evolution of saltrelated structures in compressional settings in Jackson, M.P.A., Roberts, D.G., Snelson, S. (eds.), Salt Tectonics: A Global Perspective: American Association of Petroleum Geologists Memoir, 65, 41-60.

Macías, E., 2007, Estilos estructurales en el golfo de México frente a la costa de Tamaulipas, in Simposio Asociación Mexicana de Geólogos Petroleros, Delegación Tampico, Evaluación de Plays: Tampico, Tamps., Mexico, Hábitat de Hidrocarburos, 8-9 Noviembre, 2007, Resúmenes, <http://www. amgp.org/ws/images/stories/simposium/SimposioAMGPPlaysTampico. pdf $>$, consulted: february 12, 2015.

Mauduit, T., Guérin, G., Brun, J.-P., Lecanu, H., 1997, Raft tectonics: the effects of basal slope value and sedimentation rate on progressive extension: Journal of Structural Geology, 19, 1219-1230.

Morales, C., 2009, Deep Water Exploration Strategy, Pemex, Available on line <http://www.pemex.com/files/content/deepwater_0905071.pdf >, consulted: february 12, 2015.

Ortiz-Ubilla, A., Tolson, G., 2004, Interpretación estructural de una sección sísmica en la región Arcabuz-Culebra de la Cuenca de Burgos, NE de México: Revista Mexicana de Ciencias Geológicas, 21(2), 226-235.

Peel, F.J., Travis, C.J., Hossack, J.R., 1995, Genetic structural provinces and salt tectonics of the Cenozoic offshore U.S. Gulf of Mexico: a preliminary analysis, in Jackson, M.P.A., Roberts, D.G., Snelson, S. (eds.), Salt Tectonics, A Global Perspective: American Association of Petroleum Geologists Memoir, 65, 153-175.

Pérez-Cruz, G.A., 1992, Geologic Evolution of the Burgos Basin, Northeastern Mexico: Houston, Texas, Rice University, Ph.D. thesis, 155 pp.

Pindell, J.L., Kennan, L., 2007, Rift models and the salt-cored marginal wedge in the northern Gulf of Mexico: implications for deep water Paleogene Wilcox deposition and basin-wide maturation, in $27^{\text {th }}$ Annual Bob F. Perkins Research Conference: Houston, Texas, Transactions of the Gulf Coast Association of Geological Societies and Society of Economic Paleontologists and Mineralogists, 146-186.

Radovich, B., Moon, J., Connors, C., Bird, D., 2007, Insights into structure and stratigraphy of the northern Gulf of Mexico from 2D pre-stack depth migration imaging of mega-regional onshore to deep water, long-offset seismic data: Transactions of the Gulf Coast Association of Geological Societies, 57, 633- 637 .

Ramberg, H., 1981, Gravity, deformation and Earth's crust in theory, experiments and geological application (2nd Edition): London, Academic Press, $452 \mathrm{pp}$.

Rangin, C., Le Pichon, X., Flotté, N., Husson, L., 2008, Tertiary extension in the northern Gulf of Mexico, a new interpretation of multi-channel seismic data: Bulletin de la Societé Géologique de France, 179(2), 117-128.

Rowan, M.G., 1995, Structural Styles and Evolution of Allochthonous Salt, Central Louisiana Outer Shelf and Upper Slope, in Jackson, M.P.A., Roberts, D.G., Snelson, S. (eds.), Salt tectonics: a global perspective: American Association of Petroleum Geologists Memoir, 65, 199-228.

Rowan, M.G., Weimer, P., 1998, Salt-Sediment Interaction, Northern Green Canyon and Ewing Bank (Offshore Louisiana), Northern Gulf of Mexico: American Association of Petroleum Geologists Bulletin, 82(5b), 1055-1082.

Rowan, M.G., Peel, F.J., Vendeville, B.C., 2004, Gravity-driven fold belts on passive margins, in McClay, K.R. (ed.), Thrust Tectonics and Hydrocarbon Systems: American Association of Petroleum Geologists Memoir, 82, 157-182.

Rowan, M.G., Peel, F.J., Vendeville, B.C., Gaullier, V., 2012, Salt tectonics at passive margins: geology versus models - discussion: Marine and Petroleum Geology, 37(1), 184-194.

Salazar, J.A., Knapp, J.H., Knapp, C.C., Pyles, D.R., 2013, Salt tectonics and Pliocene stratigraphic framework at MC-118, Gulf of Mexico: An integrated approach with application to deep-water confined structures in salt basins: Marine and Petroleum Geology, 50, 51-67, DOI: 10.1016/ 
j.marpetgeo.2013.11.003

Salvador, A., 1987, Late Triassic-Jurassic paleogeography and the origin of the Gulf of Mexico: American Association of Petroleum Geologists Bulletin, $71,419-451$.

SENER (Secretaria de Energía), SHCP (Secretaria de Hacienda y Credito Público), and CNH (Comisión Nacional de Hidrocarburos), 2015, Reforma Energética: Ronda 1 (Sesiones Técnicas). <http://www.energia. gob.mx/rondauno/_doc/Reforma\%20Energetica\%20Ronda\%201\%20 Sesiones.pdf $>$, consulted February 12, 2015.

Spiers, C.J., Schutjens, P.M.T.M., Brzesowsky, R.H., Peach, C.J. Liezenberg, J.L. Zwart, H.J., 1990, Experimental determination of constitutive parameters governing creep of rock salt by pressure solution, in Knipe R.J., Rutter E.H. (eds.), Deformation Mechanisms, Rheology and Tectonics: Geological Society of London Special Publications, 54, 215-227.

Talbot, C.J., 1993, Spreading of salt structures in the Gulf of Mexico: Tectonophysics, 228, 151-166.

Trudgill, B.D., Rowan, M.G., Fiduk, J.C., Weimer, P., Gale, P.E., Korn, B.E., Phair, R.L., Gafford, W.T., Roberts, G.R., Dobbs, S.W., 1999, The Perdido fold belt, northwestern deep Gulf of Mexico, part 1: structural geometry, evolution and regional implications: American Association of Petroleum Geologists Bulletin, 83, 88-113.

Urai, J.L., Spiers, C.J., Lister, G.S., 1986, Weakening of rock salt by water during long-term creep: Nature, 324, 554-557.

Vendeville, B.C., 2005, Salt tectonics driven by sediment progradation: Part IMechanics and kinematics: American Association of Petroleum Geologists Bulletin, 89, 1071-1079.

Vendeville, B., Cobbold, P.R., 1987, Glissements gravitaires synsedimentaires et failles normales listriques: modeles experimentaux: Comptes Rendus de l'Academie des Sciences, 305, 1313-1319.

Vendeville, B.C., Jackson, M.P.A., 1992, The rise of diapirs during thin-skinned extension: Marine and Petroleum Geology, 9, 331-353.
Ye, H., 1997, The arcuate Sierra Madre Oriental orogenic belt, NE Mexico: Tectonic infilling of a recess along the southwestern North American continental margin, in Soegaard K., Giles K., Vega, F., Lawton T. (eds.), Structure, stratigraphy and paleontology of Late Cretaceous-early Tertiary Parras-La Popa Foreland Basin near Monterrey, Mexico, in Dallas, Texas, American Association of Petroleum Geologists Field Trip Guidebook, Field Trip no. 10, 82-115.

Weijermars, R., Jackson, M.P.A., Vendeville, B.C., 1993, Rheological and tectonic modeling of salt provinces: Tectonophysics, 217, 143-174.

Weijermars, R., Schmeling, H., 1986, Scaling of Newtonian and non-Newtonian fluid dynamics without inertia for quantitative modeling of rock flow due to gravity (including the concept of rheological similarity): Physics of the Earth and Planetary Interiors, 43, 316-329.

Wu, S., Bally, A.W., Cramez, C., 1990, Allochthonous salt, structure and stratigraphy of the north-eastern Gulf of Mexico. Part II: Structure: Marine and Petroleum Geology, 7, 334-370.

Wu, Z., Yin, H., Wang, X., Zhao, B., Zheng, Z., Wang, X., Wang, W., 2015, The structural styles and formation mechanism of salt structures in the Southern Precaspian Basin: Insights from seismic data and analog modeling: Marine and Petroleum Geology, 62, 58-76, http://dx.doi. org/10.1016/j.marpetgeo.2015.01.010.

Manuscript received: february 15, 2018

Corrected manuscript received: august 17, 2018

Manuscript accepted: september 3, 2018 